\title{
Chelidonium majus - an Integrative Review: Traditional Knowledge versus Modern Findings
}

\author{
Marilena Gilca $^{a, b}$ Laura Gaman ${ }^{a, b}$ Elena Panait ${ }^{a} \quad$ Irina Stoian $^{a, b} \quad$ Valeriu Atanasiu $^{a}$ \\ a Biochemistry Department, Faculty of Medicine, 'Carol Davila' University of Medicine and Pharmacy, Bucharest, \\ ${ }^{\mathrm{b}} \mathrm{R}$ and D IRIST LABMED SRL, Bucharest, Romania
}

\section{Keywords}

Chelidonium majus - Greater celandine - Medicinal plant . Phytotherapy · Chinese medicine · Integrative medicine

\section{Summary}

Chelidonium majus L. (family Papaveraceae), or greater celandine, is an important plant in western phytotherapy and in traditional Chinese medicine. Crude extracts of C. majus as well as purified compounds derived from it exhibit a broad spectrum of biological activities (antiinflammatory, antimicrobial, antitumoral, analgesic, hepatoprotective) that support some of the traditional uses of $C$. majus. However, herbal medicine also claims that this plant has several important properties which have not yet been scientifically studied: $C$. majus is supposed to have diuretic, antitussive and eye-regenerative effects. On the other hand, C. majus also has scientifically proven effects, e.g. anti-osteoporotic activity and radioprotection, which are not mentioned in traditional sources. Moreover, recent controversy about the hepatoprotective versus hepatotoxic effects of Chelidonium majus has renewed the interest of the medical community in this plant. This review is intended to integrate traditional ethno-medical knowledge and modern scientific findings about $C$. majus in order to promote understanding of its therapeutic actions as well as its toxic potential.

\section{Schlüsselwörter}

Chelidonium majus · Großes Schöllkraut · Heilpflanze · Phytotherapie · Chinesische Medizin · Integrative Medizin

\section{Zusammenfassung}

Chelidonium majus L. (Familie der Papaveraceae), das große Schöllkraut, ist eine wichtige Pflanze in der westlichen Phytotherapie und in der traditionellen chinesischen Medizin. Sowohl Rohextrakte von C. majus als auch isolierte Einzelsubstanzen zeigen ein breites Spektrum an biologischen Aktivitäten (entzündungshemmende, antimikrobielle, antitumorale, analgetische, hepatoprotektive), die im Einklang mit einigen traditionellen Verwendungen von C. majus stehen. Dennoch betont die Kräutermedizin auch, dass diese Pflanze verschiedene Eigenschaften hat, die noch nicht wissenschaftlich untersucht worden sind, z.B. ihre diuretische, antitussive und augenregenerative Wirkung. Es gibt jedoch auch wissenschaftlich nachgewiesene Wirkungen, die in traditionellen Quellen nicht beschrieben sind, z.B. die Hemmung von Osteoporose oder den Schutz vor Strahlen. Darüber hinaus haben aktuelle Kontroversen über die hepatoprotektiven versus hepatotoxischen Effekte von C. majus das Interesse der Medizin an dieser Pflanze neu geweckt. Dieser Übersichtsartikel soll das ethnomedizinische, traditionelle Wissen über C. majus und moderne wissenschaftliche Erkenntnisse integrieren, um zu einem besseren Verständnis der therapeutischen Wirkungen und des toxischen Potenzials dieser Heilpflanze zu gelangen.

\begin{tabular}{ll}
\hline KARGER & @ 2010 S. Karger GmbH, Freiburg \\
Fax +497614520714 & $\begin{array}{l}\text { Accessible online at: } \\
\text { Information@Karger.de } \\
\text { www.karger.com }\end{array}$ \\
\end{tabular}




\section{Introduction}

Chelidonium majus L. (family Papaveraceae) is a plant highly praised for its therapeutic potential in western phytotherapy and traditional Chinese medicine (TCM). Popular names of the plant are: greater celandine, swallow-wort, or bai-qu-cai in Chinese.

The plant contains, as major constituents, isoquinoline alkaloids (such as sanguinarine, chelidonine, chelerythrine, berberine, protopine and coptisine), flavonoids, and phenolic acids [1]. Both crude extracts of $C$. majus and purified compounds derived from it exhibit a wide variety of biological activities (anti-inflammatory, antimicrobial, immunomodulatory, antitumoral, choleretic, hepatoprotective, analgesic, etc.) which are in concordance with the traditional uses of $C$. majus.

In this article, the pharmacological properties of $C$. majus according to scientific data will be reviewed in view of traditional claims, in order to create a synthetic description of this medicinal plant. Therapeutic properties claimed by herbal medicine but not yet studied by scientists (e.g. diuretic activity, and beneficial effects in eye diseases) as well as biological activities revealed by scientific tools, but until now unknown to traditional medicine (e.g. radioprotective or anti-osteoporotic activity) will also be mentioned.

A literature search using PubMed and Highwire was conducted to collect data from studies on pharmacological effects of C. majus. All data collected were published in English or German and available up to March 2010. 'Chelidonium majus' and 'great celandine' were used as search terms. A supplementary hand search of the references in the identified articles and of different traditional or modern medical books was performed.

\section{Description of Chelidonium majus}

Description of Chelidonium majus in Western Phytotherapy C. majus belongs to the large family of bitter tonic herbs. The medicinal virtues attributed to it are those of powerful deobstruent (particularly efficacious in removal of obstructions of the liver), analgesic, aperient, diuretic, sudorific, expectorant, and purgative. It has traditionally been used in western phytotherapy to treat liver diseases, gastric ulcer, oral infections, pain, skin eruptions, and tuberculosis. Externally, the juice of the plant has long been known as a popular remedy to remove warts, to heal old and non-responsive skin ulcers, and to remove opacities of the cornea (mixed with water as an eye water) [2-5].

\section{Description of Chelidonium majus in Traditional Chinese Medicine}

C. majus or bai-qu-cai belongs to the class of heat-clearing plants, having a cooling nature. As it also has a drying effect, it is a good remedy for conditions associated with damp heat, which may be related to congested bile or yellow discharge, and hence associated with infections (note: in Chinese medicine, heat and infections go together). In traditional Chinese medicine C. majus is mainly used to treat blood stasis (a kind of blockage in blood circulation due to stagnation of qi), to relieve pain (abdominal pain, digestive ulcer pain, cramps after meals, menstrual pain, etc.), to promote diuresis in oedema, ascites, to treat jaundice, and to relieve cough. Some of these effects (e.g. the analgesic and hepatoprotective effects) have already been recognised by modern medicine and will be discussed further [6, 7]. C. majus has a bitter taste. According to Chinese medicine, bitter taste affects the heart. However, a direct effect of C. majus on cardiac tissue has not yet been confirmed in research studies. The sole possible indirect correlation is supported by the antiplatelet effect of sanguinarine and protopine $[8,9]$ which might be useful in cardiovascular diseases.

\section{Pharmacological Activities of Chelidonium majus}

\section{Anti-Inflammatory Activity}

Animal studies: C. majus methanol extract significantly suppressed the progression of collagen-induced arthritis in mice. This action was characterized by a decreased production of TNF-alpha, IL-6, Interferon(IFN)-gamma, B cells, gammadelta $\mathrm{T}$ cells (in spleen) and an increased proportion of CD4+CD25+ regulatory T cells. The serum levels of IgG and IgM RA factors were decreased [10].

Hypothesis: The anti-inflammatory activity of C. majus could be related to its heat-clearing and blood stasis-removing actions as mentioned in traditional sources. The traditional use of $C$. majus for different types of inflammatory pain (e.g. menstrual pain) is also based, at least in part, on this pharmacological activity.

\section{Antimicrobial Activity}

C. majus is listed among one of the most active antimicrobial plants in a screening study by Kokoska et al. [11]. Crude extracts of and several alkaloids isolated from C. majus exhibited antibacterial, antiviral, and antifungal properties [11-24] (table 1).

\section{Immunomodulatory Activity}

In vitro studies: An interesting immunomodulatory potential was exhibited by a protein-bound polysaccharide extracted from C. majus (CM-Ala), which showed mitogenic activity on spleen cells, bone marrow cells, and increased the number of granulocyte macrophage-colony forming cells (GM-CFC) [25]. When C. majus extract was used in combination with recombinant IFN-gamma, there was a marked combined induction of NO and TNF-alpha production in mouse peritoneal macrophages [26]. 
Table 1. Antimicrobial activities exhibited by $C$. majus constituents and extracts

\begin{tabular}{|c|c|c|}
\hline Chemical constituents or parts used & Microbes & References \\
\hline \multicolumn{3}{|l|}{ Antibacterial activity } \\
\hline Root extract & $\begin{array}{l}\text { Bacillus cereus } \\
\text { Staphylococcus aureus }\end{array}$ & 11 \\
\hline Chelerythrine & Streptococcus mutans & 13,14 \\
\hline $\begin{array}{l}\text { 8-Hydroxydihydrosanguinarine } \\
\text { 8-Hydroxydihydrochelerythrine } \\
\text { Glycoprotein CML } \\
\text { Lectin }\end{array}$ & $\begin{array}{l}\text { Staphylococci } \\
\text { methicillin-resistant Staphylococcus aureus } \\
\text { (MRSA) }\end{array}$ & $12,15,16$ \\
\hline $\begin{array}{l}\text { Glycoprotein CML } \\
\text { Lectin }\end{array}$ & multiresistant enterococci & 15,16 \\
\hline Sanguinarine & $\begin{array}{l}\text { gram-positive bacteria, particularly Bacillus anthracis } \\
\text { and staphylococci } \\
98 \% \text { of the isolates from human dental plaque }\end{array}$ & 17,18 \\
\hline \multicolumn{3}{|l|}{ Antiviral activity } \\
\hline A new substance isolated from Chelidonium majus & human immunodeficiency virus 1 (HIV-1) & 23 \\
\hline The totality of Chelidonium majus alkaloids & herpesvirus, poxvirus, grippevirus & 24 \\
\hline \multicolumn{3}{|l|}{ Antifungal activity } \\
\hline $\begin{array}{l}\text { Root extract and aerial part extract } \\
\text { 8-Hydroxylated alkaloids (8-hydroxydihydrosanguinarine } \\
\quad \text { and 8-Hydroxydihydrochelerythtine) }\end{array}$ & $\begin{array}{l}\text { Candida albicans } \\
\text { Fusarium oxysporum } \\
\text { Botrytis cinerea } \\
\text { clinical drug-resistant yeast isolates }\end{array}$ & $11,19-22$ \\
\hline
\end{tabular}

Animal studies: C. majus extract $(1.25 \mathrm{ml} / \mathrm{kg}$ in single dose) suppressed immune responses locally by decreasing epidermal Langerhans cells and contact hypersensitivity by UVA irradiation in mice [19].

Human clinical studies: A clinical study showed that $C$. majus tincture improved cellular and humoral immunity, nonspecific resistance and promoted a reduction in the number of recurrences in children with chronic tonsillitis [27].

Hypothesis: Damp and heat produce each other. According to TCM the centre of this damp-heat pathology primarily lies in the spleen and stomach, as the spleen is the organ of damp and the stomach is the sea of food and water [28]. Low immunity and repeated infections represent one of the manifestations of damp-heat. Immunomodulatory activity including the mitogenic activity on spleen cells, and also gastroprotective [29] effects might be related with the drying and heat-clearing actions of $C$. majus and its traditional use in conditions associated with damp-heat.

\section{Gastroprotective and Anti-Ulcerogenic Activities}

Animal studies: An extract of C. majus has demonstrated anti-ulcerogenic activity against indomethacin-induced gastric ulcers in rats as well as antisecretory and cytoprotective activities. The anti-ulcerogenic activity was associated with an increase in prostaglandin E2 release and a decrease in leukotrienes [29].

\section{Choleretic Activity}

In vitro studies: Stimulatory effects of $C$. majus extract, and of alkaloid and phenolic fractions from it, have been reported on bile acid-independent flow in isolated perfused rat liver. After $40 \mathrm{~min}$, the amount of bile was more than twice the initial value and the bile acid concentration was reduced. This effect could not be assigned to one of the two isolated fractions [30].

Human clinical studies: Two studies have confirmed the choleretic effect of $C$. majus in subjects with liver diseases and healthy volunteers. A hydroethanolic extract containing $1.5 \%$ of total alkaloids calculated as chelidonine administered intragastrically increased bile flow [31, 32]. Three more studies, cited by ESCOP, have shown the capacity of C. majus to ameliorate the biliary related complaints (table 2) [33-36].

\section{Hepatoprotective Activity}

Animal studies: The ethanolic whole extract exerted marked hepatoprotection against carbon tetrachloride toxicity in two studies on rats, indicated by a reduction in the number of necrotic cells, a prevention of fibrotic changes, and decreased activities of transaminases and bilirubin $[37,38]$. It was also efficient in combating p-dimethylaminoazobenzene-induced hepatocarcinogenesis in mice [39].

Hypothesis: Choleretic and hepatoprotective activities of C. majus might be related to a deobstruent action on liver as mentioned in western phytotherapy sources. 
Table 2. Clinical studies on $C$. majus' capacity to ameliorate biliary complaints

\begin{tabular}{|c|c|c|}
\hline Study type [reference] & Daily dosage & Ameliorated complaints \\
\hline $\begin{array}{l}\text { Double blind placebo controlled } \\
\text { study, } 60 \text { patients [34] }\end{array}$ & $\begin{array}{l}700 \mathrm{mg} \text { of a hydroalcoholic extract } 5.3-7.7: 1 \\
\text { corresponding to } 24 \mathrm{mg} \text { of total alkaloids, } 6 \text { weeks }\end{array}$ & $\begin{array}{l}\text { epigastric complaints or cramps in the } \\
\text { biliary system and/or upper gastrointestinal } \\
\text { tract }\end{array}$ \\
\hline $\begin{array}{l}\text { Retrospective study, } 206 \text { patients, } \\
\quad 6 \text { months [35] }\end{array}$ & $\begin{array}{l}\text { solid preparation containing } 125 \mathrm{mg} \text { of a } \\
\text { hydroalcoholic extract corresponding to } 0.675 \mathrm{mg} \\
\text { of chelidonine and/or liquid preparation } 3 \times 20 \\
\text { drops corresponding to } 0.15 \mathrm{mg} \text { of chelidonine }\end{array}$ & $\begin{array}{l}\text { complaints related to gall stones or } \\
\text { cholecystectomy such as bloating, } \\
\text { flatulence, diarrhoea or constipation, } \\
\text { lasting abdominal pain, food intolerance }\end{array}$ \\
\hline $\begin{array}{l}\text { Multicentric prospective observational } \\
\text { study, } 608 \text { patients [36] }\end{array}$ & $\begin{array}{l}375-500 \mathrm{mg} \text { of a hydroethanolic extract } 5-7: 1 \text {, } \\
\text { corresponding to } 9-12 \mathrm{mg} \text { of total alkaloids, } 22 \text { days }\end{array}$ & $\begin{array}{l}\text { dyspeptic complaints or cramp-like pains } \\
\text { in the upper gastrointestinal tract }\end{array}$ \\
\hline
\end{tabular}

\section{Anticancer Activity}

In vitro studies: Different alkaloids of $C$. majus have the following activities that might be responsible for its anticancer effect: (a) reduced telomerase activity by chelidonine [40]; (b) cancer cell death by apoptosis [40-42], and blister cell death [42]; (c) arrest of mitosis by inhibition [40]. Several studies suggest that Ukrain ${ }^{\mathrm{TM}}$ (an anticancer drug whose major components are C. majus alkaloids chelidonine, sanguinarine, chelerythrine, protopine, and allocryptine) [41] exerts multiple selective effects on cancer cells: (a) cytotoxic effects on cancer cells without negative effects on normal cells [43]; (b) radio-sensitising effects on cancer cells, but radio-protective effects on normal cells [44].

Animal studies: C. majus extract has exerted inhibitory activity on glandular stomach carcinogenesis in rats treated with $\mathrm{N}$-methyl-N'-nitro-N nitrosoguanidine (MNNG) and hypertonic sodium chloride [45].

Human clinical studies: Some clinical studies suggest beneficial effects of Ukrain in the treatment of patients suffering from bladder, breast, pancreatic, rectal, colorectal cancer, or Kaposi's sarcoma with even less adverse reactions when compared with conventional antineoplastic drugs. However, independent rigorous clinical studies and larger sample sizes are required before positive recommendations can be issued [46-49].

Hypothesis: According to Chinese medicine, blood stasis, pathogenic heat, and static phlegm are the principal causes for most cases of cancer pathogenesis [50]. Blood stasis is assumed to produce an accumulation of heat. An accumulation of excessive fluids followed by stasis and heat thickens the dampness which becomes sticky and turns into phlegm. The anticancerous potential of $C$. majus according to Chinese medicine is due to its multiple activities: elimination of blood stasis (antithrombotic, anti-inflammatory effect) and clearing the pathogenic heat (anti-inflammatory effect), and prevention of an accumulation of body fluids.

\section{Analgesic and Antispasmodic Activity}

In vitro studies: The aqueous extract of $C$. majus suppressed glycine and gamma-aminobutyric acid (GABA) activated ion currents and elevated glutamate-activated ion currents in rat periaqueductal gray neurons, which represent a key structure of the descending pain control system [51, 52]. C. majus alkaloids also have an analgesic effect, similar to that of morphine, which may last 4-48 hours [6]. In addition, extracts of the herb C. majus, as well as isolated alkaloids, exhibited antispasmodic and relaxant effects on the abdominal and gastrointestinal muscles of animals, being especially efficient in treating abdominal pain $[53,54]$

Human clinical studies: A dried extract of Chelidonium (5-10:1 / 131-104 mg, equivalent to $4 \mathrm{mg}$ total alkaloids calculated as chelidonine) and Curcuma (12,5-25:1 / $45 \mathrm{mg}$ ) was given to 39 patients with dumpy or colicky abdominal pain in the right upper quadrant due to biliary dyskinesia, while placebos were given to 37 patients for 3 weeks, respectively. The reduction of pain was more rapid during the first treatment week in patients who received the extract than in patients who received placebos [55].

Hypothesis: In Neijing chapter 39, the Yellow Emperor says that when the continuous flow of qi and blood through the body within their channels is attacked by a cold pathogen, it stagnates and creates pain [28]. C. majus' capacity to modulate ion currents in neurons and to relax muscles might be an expression of the herb's potential to remove qi stasis.

\section{Radioprotective Activity}

An extract of $C$. majus (CM-Aia) was found to increase the number of bone marrow cells, spleen cells, GM-CFC, platelets and to favour survival at lethal doses in irradiated mice [56]. Also, Ukrain minimized the consequences of irradiation in the endocrine system of the trial animals (abnormal glucocorticoid reception) [57].

\section{Anti-Osteoporotic Properties}

Ukrain, when administered intraperitoneally to ovariectomized mature female rats, prevented the decrease of bone mineral density of the femur measured by energy x-ray absorptiometry densitometry [56], and increased the electron paramagnetic resonance (EPR) signal intensity of the femur [59]. These effects are most probably related to an increased production of estrogens [60]. 
Table 3. Hypothetical correspondences between traditionally recognised and scientifically proved activities of Chelidonium majus

\begin{tabular}{|c|c|c|c|}
\hline Traditional data & References & Scientific data & References \\
\hline \multicolumn{4}{|c|}{ I. Traditional therapeutic actions confirmed or correlated with scientific findings } \\
\hline Deobstruent used in liver diseases and jaundice & $2,4,5$ & $\begin{array}{l}\text { hepatoprotective } \\
\text { choleretic }\end{array}$ & $22,30,31,37-39,55$ \\
\hline Healing skin ulcers and gastric ulcers & 2,6 & gastroprotective & 29 \\
\hline $\begin{array}{l}\text { Anodyne used for the treatment of various kinds of pains } \\
\text { (e.g. tooth ache, abdominal pain, menstrual pain, etc.) }\end{array}$ & $2,6,7$ & $\begin{array}{l}\text { analgesic } \\
\text { anti-inflammatory } \\
\text { spasmolytic }\end{array}$ & $\begin{array}{l}9,10,25,36,51 \\
52-55\end{array}$ \\
\hline $\begin{array}{l}\text { Heat clearing plant used in fevers and conditions } \\
\text { associated with damp heat, such as infections, } \\
\text { cancers }\end{array}$ & 6,7 & $\begin{array}{l}\text { antimicrobial } \\
\text { immunomodulatory } \\
\text { antioxidant }\end{array}$ & $\begin{array}{l}11-18,20,21,24 \\
26,27,61,62\end{array}$ \\
\hline Cleansing, alterative or eliminating toxins & $2,5,6$ & $\begin{array}{l}\text { antitumoral } \\
\text { anticancer } \\
\text { immunomodulatory } \\
\text { antioxidant }\end{array}$ & $\begin{array}{l}64,26,40,42,43 \\
45-49 \\
61,62\end{array}$ \\
\hline Eliminate blood stasis & 7 & $\begin{array}{l}\text { antithrombotic } \\
\text { anti-inflammatory }\end{array}$ & $8-10$ \\
\hline Removal of warts & 4,5 & $\begin{array}{l}\text { immunomodulatory } \\
\text { antiviral }\end{array}$ & $\begin{array}{l}19,23,24, \\
25-27\end{array}$ \\
\hline \multicolumn{4}{|c|}{ II. Traditional therapeutic actions not yet confirmed by scientific findings } \\
\hline Drying effect, diuretic and useful in edema & 2,6 & - & - \\
\hline $\begin{array}{l}\text { Expectorant, antitussive, useful in chronic bronchitis, } \\
\text { pulmonary consumption, whooping cough }\end{array}$ & 5,6 & - & - \\
\hline Eye regenerative and removal of corneal opacities & 3,4 & - & - \\
\hline \multicolumn{4}{|c|}{ III. Scientific findings not specified in traditional sources or not correlated with traditional actions } \\
\hline- & - & antiosteoporotic & $58-50$ \\
\hline- & - & radioprotective & $44,56,57$ \\
\hline- & - & $\begin{array}{l}\text { neuroprotective potential } \\
\text { (acetylcholinesterase inhibitor) }\end{array}$ & 71 \\
\hline
\end{tabular}

\section{Antioxidant versus Pro-Oxidant Activity}

Although alcoholic extract of $C$. majus showed strong antioxidant activity measured by different assays, e.g. 1,1-diphenyl-2-picrylhydrazyl radical scavenging assay or FRAP assay [61, 62], this does not depend on the alkaloid content of the drug or transition metal element content [61]. There is also an animal study that reported a slight but significant reduction of glutathione level and SOD activity in the liver, after oral administration of a massive dose of C. majus (1.5-3 g / kg / day) [63]. These results suggest that, in spite of its intrinsic antioxidant properties, C. majus might compromise the hepatic antioxidant protection in case of overdose.

\section{Toxic Potential}

C. majus exhibited several types of toxicity: cytotoxicity on tumoral cells, hepatotoxicity, and phototoxicity.

Cytotoxicity: Both Chelidonium extract and isolated alkaloids showed cytotoxic effects towards murine NK/Ly lymphoma cells, possessing DNA intercalating properties and DNA damaging capacity [64].
Hepatotoxicity: Several isolated cases of hepatotoxicity (e.g. acute cholestatic hepatitis) of $C$. majus have been reported [65-68]. All patients completely recovered after withdrawal of Chelidonium. Clinical recovery was rapid and the hepatic functions returned to normal within few months $[65,66]$. In addition to these cases, some 40 cases of liver damage from $C$. majus have been reported to the German regulatory authorities [69]. Based on this data, C. majus has been banned from oral use in Germany and other European countries. There is also an animal study that found no hepatotoxicity at doses about 50-100 times higher than those generally used in humans [63]. An average daily oral dose of alkaloids (sanguinarine: chelerythrine 3:1) up to $5 \mathrm{mg} / 1 \mathrm{~kg}$ animal body weight proved to be safe [88]. Based on a careful examination of the available evidence linking ingestion of $C$. majus with isolated cases of hepatotoxicity, the Australian Complementary Medicines Evaluation Commitee has recently recommended that all oral products containing $C$. majus have a warning label and be used under professional health-care supervision [70].

Phototoxicity: Plant extract-induced sunburn oedema and formation of sunburn cells in mice [19]. 
Fig. 1. Hypothesis on the pharmacological activities of $C$. majus in relation to Chinese indications. Elimination of blood stasis by Chelidonium might be correlated with antithrombotic, anti-inflammatory, and analgesic activities. Clearing the pathogenic heat might be correlated with anti-inflammatory, antiinfectious, anticancer, and antioxidant activities.

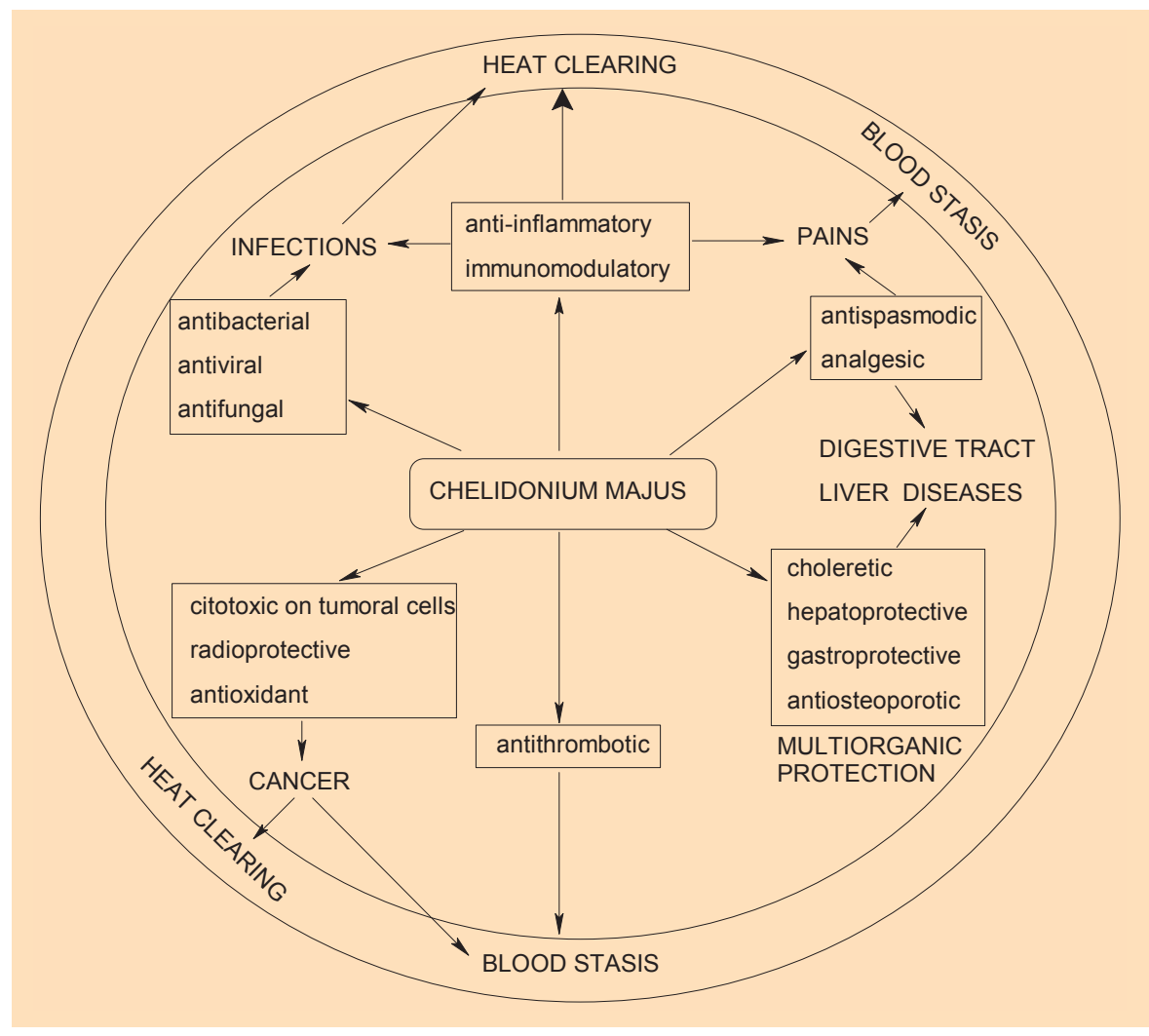

\section{Conclusions}

Despite major difficulties in explaining the traditional concepts in modern scientific language, we suggest further tests of several hypothetical equivalences concerning the therapeutic activities of $C$. majus (table 3 ).

The equivalence is not perfect or univocal: a single traditional term is usually explained by several modern terms. Modern terms also tend to be more specific than traditional terms (fig. 1).

We also have to take into consideration that the ancient non-quantifiable criteria for quality assessment (e.g. wet-dry, cold-hot) of herbal activities can not be replaced by simple biochemical or pharmacological measurements. Hence, to date an integration of TCM concepts into modern medicine is only possible to a limited degree, due to the fact that our pre- vious scientific experience is mainly based on the quantitative evaluation of different biological parameters. On the other hand, the qualitative aspects, which are primordial in Chinese medicine, are almost completely ignored. The gap between these two systems will be filled when new scientific tools adequate for analyzing the qualities will be developed. Further fundamental studies and clinical trials are required in order to confirm the latent therapeutic potential of $C$. majus mentioned in traditional texts, and to find better ways of assessing the selective cytotoxic potential of this plant.

\section{Disclosure Statement}

There is no conflict of interests and this study has not been supported by any grant.

\section{References}

1 Colombo ML, Bosisio E: Pharmacological activities of Chelidonium majus L. (Papaveraceae). Pharmacol Res 1996;33(2):127-34.

2 Culpeper N: Culpeper's Complete Herbal. A Book of Natural Remedies for Ancient Ills. Hertfordshire, Wordsworth, 1995
3 Mills S, Bone K, Corrigan D, Duke JA, Wright JV: Principles and practice of phytotherapy: modern herbal medicine. Edinburgh, Churchill Livingstone, 2008.

4 Thornton RJ: A New Family Herbal: or, Popular Account of the Natures and Properties of the Various Plants Used in Medicine, Diet, and the Arts. London, Philipps, 1810
5 Stephenson J, Churchill JM, Burnett GT: Medical Botany; or, Illustrations and Descriptions of the Medicinal Plants. London, Medical Bookseller and Publisher, 1864

6 Huang CK: The Pharmacology of Chinese Herbs, ed 2. Boca Raton, FL, CRC, 1999 
7 Tierra M: Planetary Herbology: An Integration of Western Herbs into the Traditional Chinese and Ayurvedic Systems. Sante FE, NM, Lotus), 1992, pp 209-210.

8 Jeng JH, Wu HL, Lin BR, Lan WH, Chang HH, Ho YS, Lee PH, Wang YJ, Wang JS, Chen YJ, Chang MC: Antiplatelet effect of sanguinarine is correlated to calcium mobilization, thromboxane and cAMP production. Atherosclerosis 2007; 191(2):250-258.

9 Saeed SA, Gilani AH, Amjoo RU, Shah BH: Antithrombotic and anti-inflammatory activities of protopine. Pharmacol Res 1997;37:1-7.

10 Lee YC, Kim SH, Roh SS, Choi HY, Seo YB: Suppressive effects of Chelidonium majus methanol extract in knee joint, regional lymph nodes, and spleen on collagen-induced arthritis in mice. J Ethnopharmacol 2007;112(1):40-48.

11 Kokoska L, Polensky Z, Rada V, Nepovim A, Vanek T: Screening of some Siberian medicinal plants for antimicrobial activity. J Ethnopharmacol 2002;82(1):51-53.

>12 Zuo GY, Meng FY, Hao XY, Zhang YL, Wang GC, Xu GL: Antibacterial alkaloids from Chelidonium majus Linn (Papaveraceae) against clinical isolated of methicillin-resistant Staphylococcus aureus. J Pharm Pharm Sci 2008;11(4):90-94.

13 Cheng RB, Chen X, Liu SJ, Zhang XF: [Effect of Chelerythrine on cell surface hydrophobicity and adherence of Streptococcus mutans.] Shanghai Kou Qiang Yi Xue 2007;16(1):68-72.

${ }_{14}$ Cheng RB, Chen X, Liu SJ, Zhang XF, Zhang GH: [Experimental study of the inhibitory effects of Chelidonium majus L. extractive on Streptococcus mutans in vitro.] Shanghai Kou Qiang Yi Xue 2006;15(3):318-320.

15 Fik E, Gozdzicka-Jozefiak A, Haertle T, Mirska I, Kedzia W: New plant glycoprotein against methicillin resistant staphylococci and enterococci. Acta Microbiol Pol 1997;46(3):325-327.

16 Fik E, Wołuń-Cholewa M, Kistowska M, Warchoł JB, Goździcka-Józefiak A: Effect of lectin from Chelidonium majus L. on normal and cancer cells in culture. Folia Histochem Cytobiol 2001;39(2) 215-216.

17 Garcia VP, Valdes F, Martin R, Luis JC, Alfonso AM, Ayala JH: Biosynthesis of antitumoral and bactericidal sanguinarine. J Biomed Biotechnol 2006; doi:10.1155/JBB/2006/63518.

18 Dzink JL, Socransky SS: Comparative in vitro activity of sanguinarine against oral microbial isolates. Antimicrob Agents Chemother 1985;27(4) 663-665.

-19 Bark KM, Heo EP, Han KD, Kim MB, Lee ST, Gil EM, Kim TH: Evaluation of the phototoxic potential of plants used in oriental medicine. J Ethnopharmacol 2010;127(1):11-18.

20 Matos OC, Baeta J, Silva MJ, Pinto Ricardo C: Sensitivity of Fusarium starins to Chelidonium majus L. extracts. J Ethnopharmacol 1999;66(2): 151-158.

21 Parvu M, Parvu AE, Cranium C, Barbu-Tudoran L, Tamas M: Antifungal activities of Chelidonium majus extract on Botrytis cinerea in vitro and ultrastructural changes in its conidia. J Phytopat 2008;156(9):550-552.

22 Meng F, Zuo G, Hao X, Wang G, Xiao H, Zhang J, Xu G: Antifungal activity of the benzo[c]phenanthridine alkaloids from Chelidonium majus Linn against resistant clinical yeast isolates. J Ehnopharmacol 2009;125(3):494-496.
23 Gerencer M, Turecek PL, Kistner O, Mitterer A, Savidis-Dacho H, Barrett NP: In vitro and in vivo anti-retroviral activity of the substance purified from the aqueous extract of Chelidonium majus $\mathrm{L}$. Antiviral Res 2006;72(2):153-156.

24 Lozjuk RM, Lisnyak OI, Lozjuk LV: Theoretical grounds and experimental confirmation of the antiviral effect of the preparation Ukrain. Drugs Exp Clin Res 1996;22(3-5):213-217.

25 Song JY, Yang HO, Pyo SN, Jung IS, Yi SY, Yun YS: Immunomodulatory activity of protein-bound polysaccharide extracted from Chelidonium majus. Arch Pharm Res 2002;25(2):158-164.

26 Chung HS, An HJ, Jeong HJ, Won JH, Hong SH, Kim HM: Water extract isolated from Chelidonium majus enhances nitric oxide and tumour necrosis factor-alpha production via nuclear factorkappa B activation in mouse peritoneal macrophages. J Pharm Pharmacol 2004;56(1):129-34.

27 Khmel'nitskaia Nm, Vorob'ev KV, Kliachko LL, Ankhimova ES, Kosenko VA, Tymova EV, Mal'seva GS, Medvedev EA: A comparative study of conservative treatment schemes in chronic tonsillitis in children. Vestn otorinolaringol 1998;4:39-42.

28 Ni Maoshing: The Yellow Emperor's Classic of Medicine. A New Translation of the Neijing Suwen with Commentary. London, Shambala, 1995.

29 Khayyal MT, el-Ghazaly MA, Kenawy SA, Seifel-Nasr M, Mahran LG, Kafafi YA, Okpanyi $\mathrm{SN}$ : Antiulcerogenic effect of some gastrointestinally acting plant extracts and their combination. Arzneimittelforschung 2001;51(7):545-553.

30 Vahlensieck U, Hahn R, Winterhoff H, Gumbinger HG, Nahrstedt A, Kemper FH: The effect of Chelidonium majus herb extract on choleresis in the isolated perfused rat liver. Planta Med 1995; 61:267-271.

31 Baumann JC: Über die Wirkung von Chelidonium, Curcuma, Absinth und Carduus marianus auf die Galle- und Pankreassekretion bei Hepatopathien. Med Monatsschr 1975;29:173-180.

32 Baumann JC, Heintze K, Muth HW: Klinischexperimentelle Untersuchungen der Gallen-, Pancreas- und Magensaftsekretion unter den phytocolagogen Wirkstoffen einer Carduus marianusChelidonium-Curcuma-Suspension. Arzneimittelforschung/Drug Res 1971;21:98-101.

33 ESCOP (European Scientific Cooperative on Phytotherapy) Monographs: The Scientific Foundation for Herbal Medicinal Products, ed 2. Exeter, Argyle, 2003, pp 74-78.

34 von Zerssen D: Die Beschwerden-Liste. Manual. Weinheim, Beltz Test, 1976.

35 Ardjah H: Therapeutische Aspekte der funkionellen Oberbauchbeschwerden bei Gallenwegserkrankungen. Fortschr Med 1991;109(suppl 115): $2-8$.

36 Kniebel R, Urlacher W: Therapie krampfartiger Abdominalschmerzen. Hochdosierter Schollkrautextrakt bei krampfartigen Abdominalschmerzen. Z Allg Med 1993;69:680-684.

37 Mitra S, Gole M, Samajdar K, Sur RK, Chakraborty BN: Antihepatotoxic activity of Chelidonium majus. Int J Pharmacognosy 1992;30:125-128.

-38 Mitra S, Sur RK, Roy A, Mukherjee AS: Effect of Chelidonium majus L. on experimental hepatic tissue injury. Phytother Res 1996;10:354-356

39 Biswas J, Bhattacharjee N, Khuda-Bukhsh AR: Efficacy of a plant extract (Chelidonium majus L.) in combating induced hepatocarcinogenesis in mice. Food Chem Toxicol 2008;46(5):1474-1487.
40 Noureini SK, Wink M: Transcriptional down regulation of hTERT and senescence induction in HepG 2 cells by chelidonine. World J Gastroenterol 2009:15(29):2603-3610.

41 Habermehl D, Kammerer B, Handrick R, Eldh T, Gruber C, Cordes N, Daniel PT, Plasswilm L, Bamberg M, Belka C, Jendrossek V: Proapoptotic activity of Ukrain is based on Chelidonium majus L alkaloids and mediated via a mitochondrial death pathway. BMC Cancer 2006;6:14.

42 Philchenkov A, Kaminsky V, Zavelevich M, Stoika R: Apoptogenic activity of two benzophenanthridine alkaloids form Chelidonium majus L. does not correlate with their DNA damaging effects. Toxicol in vitro 2008;22(2):287-295.

43 Hohenwarter O, Strutzenberger K, Katinger H, Liepins A, Nowicky JW: Selective inhibition of in vitro cell growth by the antitumor drug Ukrain. Drugs Exp Clin Res 1992;18(suppl):1-4

44 Cordes N, Plasswilm L, Bamberg M, Rodemann HP: Ukrain, an alkaloid thiophosphoric acid derivative of Chelidonium majus L. protects human fibroblasts but not human tumor cells in vitro against ionizing radiation. Int J Radiat Biol 2002; 78(1):17-27.

45 Kim DJ, Ahn B, Han BS, Tsuda H: Potential preventive effects of Chelidonium majus L. (Papaveraceae) herb extract on glandular stomach tumor development in rats treated with N-methyl-N' nitro-N nitrosoguanidine (MNNG) and hypertonic sodium chloride. Cancer Lett 1997;112(2):203-208.

46 Lohninger A, Hamler F: Chelidonium majus L. (Ukrain) in the treatment of cancer patients. Drugs Exp Clin Res 1992;18(suppl):73-77.

47 Gansauge F, Ramadani M, Pressmar J, Gansauge S, Muehling B, Stecker K, Cammerer G: NSC631570 (Ukrain) in the palliative treatment of pancreatic cancer. Results of a phase II trial. Langenbecks Arch Surg 2002;386(8):570-574.

48 Ernst E, Schmidt K: Ukrain - a new cancer cure? A systematic review of randomised clinical trials. BMC Cancer 2005;5(1):69.

49 Voltchek IV, Liepins A, Nowicky JW, Brzosko WJ: Potential therapeutic efficacy of Ukrain (NSC 631570) in AIDS patients with Kaposi's sarcoma. Drugs Exp Clin Res 1996;22(3-5):283-286.

50 Lahans T: Integrating Conventional and Chinese Medicine in Cancer Cure: A Clinical Guide. Philadelphia, Churchill Livingstone, 2007.

51 Shin MC, Jang MH, Chang HK, Han SM, Park HJ, Shim I, Lee JS, Kim KA, Kim CJ: Modulation of Chelidonii herba on glycine-activated and glutamate-activated ion currents in rat periaqueductal gray neurons. Clin Chim Acta 2003;337(1-2):93-101.

52 Kim Y, Shin M, Chung J, Kim E, Koo G, Lee C, Kim C: Modulation of Chelidonii herba on GABA activated chloride current in rat PAG neurons. Am J Chin Med 2001;29(2):265-279.

53 Boegge SC, Kesper S, Verspohl EJ, Nahrstedt A: Reduction of Ach-induced contraction of rat isolated ileum by coptisine, (+)caffeoylmalic acid, Chelidonium majus, and Corydalis lutea extracts. Planta Med 1996;62:173-174.

54 Hiller KO, Ghorbani M, Schilcher H: Antispasmodic and relaxant activity of chelidonine, protopine, coptisine, and Chelidonium majus extracts on isolated guinea-pig ileum. Planta Med 1998; 64(8):758-760.

55 Niederau C, Göpfert E: The effect of chelidoniumand turmeric root extract on upper abdominal pain due to functional disorders of the biliary system. Results from a placebo-controlled double-blind study. Med Klin (Munich) 1999;94(8):425-430. 
56 Song JY, Yang HO, Shim JY, Ji-Yeon-Ahn, Han YS, Jung IS, Yun YS: Radiation protective effect of an extract from Chelidonium majus. Int $\mathrm{J}$ Hematol 2003;78(3):226-232.

57 Luksa-Lichtenthaeler GL, Ladutko EI, Nowicky JW: Radiomodification effects of Ukrain, a cytostatic and immunomodulating drug, on intracellular glucocorticoid reception during short-term gamma-irradiation. Drugs Exp Clin Res 2000; 26(5-6):311-315.

58 Jabłoński M, Gorzelak M, Patyra M, JagiełłoWójtowicz E: Intermittent three-month treatment with Ukrain in intact and ovariectomized rats. Part II: Effect on bone mineral density of the femur. Drugs Exp Clin Res 2000;26(5-6):327-331.

-59 Jabłoński M, Korczak W, Gorzelak M, JagiełłoWójtowicz E: Intermittent three-month treatment with Ukrain in intact and ovariectomized rats. Part III: Effect on the native electron paramagnetic resonance signal intensity of the femur. Drugs Exp Clin Res 2000;26(5-6):333-336.

60 Jabłoński M: Ukrain (NSC-631570) influences on bone status: a review. Drugs Exp Clin Res 2000; 26(5-6):317-320.
61 Then M, Szentmihalyi K, Sarkozi A, Varga IS: Examination on antioxidant activity in the greater celandine (Chelidonium majus L.) extracts by FRAP method. Acta Biol Szeged 2003;47(1-4):115-117.

62 Nadova S, Miadokova E, Alfoldiova L, Kopaskova M, Hasplova K, Hudecova A, Vaculcikova D, Gregan F, Cipak L: Potential antioxidant activity, cytotoxic and apoptosis-inducing effects of Chelidonium majus L. extract on leukemia cells. Neuro Endocrinol Lett 2008;29(5):649-652.

63 Mazzanti G, Di Sotto A, Franchitto A, Mammola CL, Mariani P, Mastrangelo S, Menniti-Ippolito F, Vitalone A: Chelidonium majus is not hepatotoxic in wistar rats, in a 4 weeks feeding experiment. J Ethnopharmacol 2009;126(3):518-524.

64 Kaminsky V, Lootsik M, Stoika R: Correlation of the cytotoxic activity of four different alkaloids, from Chelidonium majus (greater celandine), with their DNA intercalating properties and ability to induce breaks in the DNA of NK/Ly murine lymphoma cells. Cent Eur J Biol 2006;1(1):2-15.

65 Crijns AP, de Smet PA, van den Heuvel M, Schot BW, Haagsma EB: Acute hepatitis after use of a herbal preparation with greater celandine (Chelidonium majus). Ned Tijdschr Geneeskd 2002; 146(3):100-102.
66 Rifai K, Flemming P, Manns MP, Trautwein C: Severe drug hepatitis caused by Chelidonium. Internist (Berl) 2006;47(7):749-751.

67 Haderman E, van Overbeke L, Ilegems S, Ferrante $\mathrm{M}$ : Acute hepatitis induced by greater celandine (Chelidonium majus). Acta Gastroenterol Belg 2008;71(2):281-282.

68 Moro PA, Cassetti F, Giugliano G, Falce MT, Mazzanti G, Menniti-Ippolito F, Raschetti R, Santuccio C: Hepatitis from greater celandine (Chelidonium majus L.): review of literature and report of a new case. J Ethnopharmacol 2009;124(2):328-332.

69 De Smet PA: Safety concerns about kava not unique. Lancet 2002;360(9342):1336.

70 Anonymous: Chelidonium majus. Statement to advice use under supervision. WHO Pharm Newslett 2003;4:4.

71 Cho KM, Yoo ID, Kim WG: 8-hydroxydihydrochelerythrine and 8-hydroxydihydrosanguinarine with a potent acetylcholinesterase inhibitory activity from Chelidonium majus L. Biol Pharm Bull 2006;29:2317-2320. 